\title{
研究論文＼cjkstart青年期の移行問題を通じた公害問題と教育とを巡る 環境教育研究
}

\section{一青森県六ケ所村におけるむつ小川原開発計画を事例に一}

\author{
小山田 和代 \\ 一橋大学大学院社会学研究科
}

\begin{abstract}
Environmental Education Research over the Environmental Disruption Problems and Education through Adolescents' Transition from School to Work

- A Case Study of the Development Plan of Mutsu-Ogawara in Rokkasyo village -
\end{abstract}

\author{
Kazuyo OYAMADA \\ Graduate School of Social Sciences, Hitotsubashi University
}

（受理日 2015年 10 月 30 日）

In recent years, inheritance of kogai kyoiku (education against environmental disruption) has been pointed out. However, in areas that suffer the risk of pollution, education practice itself by teachers has become more difficult.

In this study, while applying the framework of kogai kyoiku and research, for the region, which had the risk of modern environmental disruption, it is to analyze from the migration problem of adolescence for the point of view of education and environmental disruption. I discussed that education request of as a solution to the adolescence of the migration problem, rather than a straightforward education request of residents, come appear as a request associated with the pollution problem.

Key words: kougai kyoiku, Adolescents' Transition, Rokkasyo

\section{I 問題意識一現代の公害リスクを抱える地域を 環境教育研究はどう扱うのか}

高度経済成長期に頻発した日本の公害問題は、 現在でもなくなることなく、人々に様々な被害や リスクを与え続けている。高度経済成長期の公害 問題に対しては、多くの教師が公害についての教 材の開発やカリキュラムの自主編成、住民との地 域調查活動を行ったりした。日本各地で展開され たこれらの公害教育実践について、藤岡貞彦らの
教育研究者は理論化を試み環境教育へと発展させ てきた。このような公害教育について、近年は、 継承や再評価の必要性が訴えられるようになっ た。例えば日本環境教育学会編の環境教育辞典で は、公害教育を「激甚であった日本の公害の発生 を起点として、日本独自の教育として成立した教 育運動打よび教育思潮（高橋 2013 p.109）」と定 義しつつ「公害教育はすでに終わった、もしくは 廃れた教育実践（高橋 2013 p.109）」という意識 に対し、公害教育の観点が現在でも重要であるこ

問い合わせ先 sd092001@g.hit-u.ac.jp 
とを指摘している。ただし、現在において、公害 教育の観点はどのように学び継承されるべきなの であろうか。公害教育実践の継承を訴えた研究は 数多くある一方で、現代において公害のリスクを 抱える地域を対象にした研究はあまりなされてこ なかった。

現在においても公害のリスクを抱えている地域 へ目を向けると、公害教育は「すでに終わった」 や「廃れた」と言われるよりも、そもそも公害教 育実践が容易ではない社会環境がある。例えば、 原子力関連施設が建設された地域の経済的中心 は、かつては農業や漁業だったが、原子力関連産 業へと変化したことで経済的規定が強まり、地域 住民や学校教師は反対や疑問の声を挙げづらい状 況へと変化した。このような地域の社会環境の歴 史的変化は、公害教育の立脚点となった「環境破 壊の現実を教材（藤岡 1992 p.81）」とすることだ けでなく、地域の「現実」を語ることそのものを 難しくしている。公害のリスクを抱える地域の環 境教育研究はどのように行っていけばよいのだろ うか。

\section{II 公害問題と教育の「現実」の捉え方 一公害教育研究を参照した分析枠組み一}

公害のリスクを抱える地域に迫るためには、先 に挙げたような公害教育研究が参考になる。ただ し、教育実践は現代において数少ないことから、 公害教育実践の枠組みについての先行研究として ここでは宮原と藤岡の研究を中心に検討を行う。

宮原は、青年期教育研究を基盤としながら、三 島・清水・沼津石油コンビナート建設反対運動へ の学習に着目をした社会教育研究者である。宮原 がなぜ青年期教育について着目したのかを補足し ておく。宮原にとって、青年期とは、第一に戦後 の工業諸国においては産業側からの労働者の養成 と直接に対応する年齢であり、第二に資本主義国 においては、労働者階級を中心とした国民教育要 求の高まりのなかで初等教育に次いで万人の教育 として着目された年齢であった（宮原 1966）。 つまりは、産業からの要請と国民教育要求が衝突 する発達段階として、着目していたのである。そ
の上で、宮原は、資本主義社会が求める労働者を 育成するのではなく、経済から独立できる科学的 な生産人を育成することを志し、地方へ押し寄せ る工業化に対し新しい地域を地域大衆の手によっ てつくりだし、青年は青年の立場でこれに参加で きるような基礎的教授と学習とを組織していくこ とが、国民の立場に立つ教育の任務だと考えてい た（宮原 1976）。この宮原の青年期教育へのまな ざしが捉えた事例の 1 つが沼津・三島・清水石油 コンビナート建設反対運動における高校生たちの 活動であった。沼津・三島・清水石油コンビナー 卜建設反対運動を、住民大衆の力によって新しい 地域をつくりだしていこうとする基本的視点が通 底している事例として称えたのであった（宮原 1966)。

宮原が着目した公害教育実践を藤岡はどのよう に理論化しようとしたのだろうか。藤岡は教育要 求に民衆が自覚的になるために、様々な生活要求 の一環として教育要求を考え、その生活要求の一 つとしての教育環境に着目した。これらについ て、環境権と教育権の統一と称し、「<地域の再 建と教育の再建 >を環境的視角から問うことは、 『子育てと世直し』をひとつのものとしてつかむ 努力、教育本質論研究への努力の一角をなすに違 いない」と述べた（藤岡 1977 p.210）。そして、 公害教育のエッセンスを、「教育理念としての地 域環境問題と地球環境問題の統一把握、教育目標 としての環境権認識の定立、教育内容としての公 害・開発・環境問題、教育方法としての実事求是 (藤岡 2000 pp.27-28)」というように定式化した のである。

ここで、先の藤岡の「現実」について宮原にも 従い再解釈し整理すれば、「現実」とは地域の問 題である公害と教育の交差領域に浮上するもので あり、さらにそこでの葛藤は青年期教育に表れる ということであろう。ただし、宮原と藤岡は、例 えば、国民の教育要求の変化や歴史的な社会環境 の変化については詳しく描き出しておらず、この 観点に対する補強が必要になる。そこで、現代の 公害問題の多くが技術の使われ方や社会システム により発生していることから、社会と技術に関す 
る捉え方についてのザックスの指摘を参考にした い。ザックスは、近代技術は、どんな文化圈のプ ロジェクトにも適用できるように見えるが、実際 は特定の文明モデルがついて回ることは避けられ ないとし、ある技術と文化圈は連動することを指 摘している(ザックス2003)。これを当てはめれ ば、公害問題が地域や教育にある種の文明モデル を与えている、逆に言えば地域の教育要求そのも のが公害問題から影響を受けて変化しうる動的な 存在ということになる。つまり、公害そのものが 発生していなかったり被害が可視化されていな かったりしても、教育や地域は公害問題から独立 しているわけではなく連動して変化している存在 と考えられる。

以上から本稿では、公害のリスクを抱える地域 における環境教育研究を行う手始めとして、地域 や教育の変化を公害問題と関連させながら論述す る。その際、これらの関連が、葛藤としても現れ やすい青年期の移行問題に焦点を当てる。事例と しては、原子力関連施設が大規模に集積した青森 県六ケ所村とする。また、このような目的から、 第而章では六ケ所村とむつ小川原開発の概要、第 $\mathrm{IV}$ 章においては、青年期移行問題を中心とした、 地域と教育との変化を原子力施設建設に関連させ ながら論じていく。最後に、第 $\mathrm{V}$ 章においては現 代の公害のリスクを抱える地域に対して環境教育 研究が今後どのような研究していく必要があるの かを検討する。

\section{III 六ヶ所村とむつ小川原開発の概要}

青森県上北郡六ヶ所村は、青森県の東側、下北 半島に位置する。古くから倉内、平沼、鷹架、尾 駮、出戸、泊の 6 つの集落があることから明治 22 年に六ヶ所村と名づけられた。人口は 11,000 人程、 村は東西南北に非常に広くなっている。六ヶ所村 の特徵は、江戸時代からの既存集落があることに 加え、凶作を受けての分村や戦後の引揚者による 開拓集落も存在することである。また、古くから 出稼ぎが行われ、戦前は、男は漁師・農夫・杣夫 として北海道、樺太 (サハリン)、カムチャッカ 半島方面へ、女は紡績工女として関東、関西方面
へ出稼ぎにでていた（六ヶ所村村史編纂委員会 1997 p.539)。

六ヶ所村が巨大工業開発の地となったのは、 1969年に閣議了承された新全国総合開発計画に 始まる。新全国総合開発計画において、大規模臨 海工業基地の拠点として陸奥湾及び小川原湖周辺 のむつ小川原地域が指定され、国家規模の大規模 開発が計画された。1971年には、開発計画の第 一次案として、石油精製、石油化学、火力発電を 主にする施設の構想が発表された。開発に伴う開 発区域は合計で $17,400 \mathrm{ha}$ 、立ち退き人数は、約 1 万人に上った。しかし、第一次案は、ドル・ショッ クの影響もあり縮小することとなり、第二次案が 提示された。第二次案では、開発区域面積が大幅 に縮小され第一次案同様に石油精製、石油化学、 火力発電が盛り込まれたが、鉄鋼等の立地は開発 計画から削除され石油産業の立地が先行された。 また、この開発区域の縮小に伴い、第一次案は近 隣の三沢市まで含まれていたが、第二次案では 六ヶ所村が開発計画の中心地となった。ところ が、石油産業中心であった第二次案も、二度の才 イルショックの影響で高度経済成長に陰りが見え 始めていたなか頓挫した。開発公社は企業誘致に 失敗し、83 年には赤字が約 1,400 億円、未売却用 地は5,200haに達した（䑪橋 1998）。そして、石 油型開発計画が行き詰まった末に登場したのが核 燃料サイクル基地の構想である。

1985年、青森県、六ケ所村、日本原然サービ ス株式会社、日本原燃産業（後者 2 者は合併しの ちの株式会社日本原燃となる）の 4 者が電気事業 連合会を立会人として核燃立地に関する基本協定 を締結した。1988年にはウラン濃縮工場、1990 年には低レベル放射性廃棄物貯蔵センター、1992 年には高レベル放射性廃棄物貯蔵管理センター、 1993年には再処理工場、2010年にはMOX燃料 工場が着工した (1)。農業や漁業を営みながら出稼 ぎを行っていた住民の生活は、この間に大きく変 容した。村民の一人当たりの所得は、1970年に は239,373円で全国水準と比較し $41.9 \%$ あ゙あた のが、1993 年には3,052,000 円と全国水準の $102.1 \%$ 、県内との比較でも $131.6 \%$ にまで上昇し 
た（六ヶ所村 2007）。村内には、核然料サイク ル事業を担う(株)日本原燃の下請けや孫請けなど関 連会社、また建設業が増加し、少なからずの人が 核燃料サイクル事業と経済的関係性を有してい る。

\section{IV むつ小川原開発と青年期の移行問題}

むつ小川原開発のなかで、青年期の移行に係る 課題は、開発と関わりながらどのように変化した のだろうか。以下では、(1)むつ小原開発前から 石油型のむつ小川原開発計画迄（1960年代〜 1970年代)、(2)六ヶ所高等学校の開校からウラン 濃縮施設着工迄（1978年～1988年頃)、(3)む小 川原開発の本格的な核燃化以降（1988年以降） と時代区分を区切り青年期の移行の変遷を述べて いく。

\section{1 むつ小川原開発前から石油型のむつ小川原 開発計画迄一 第一次産業から第二次産業へ の転換の模索}

戦後の六ヶ所村の高等学校進学率は、全国のな かでも極めて低い水準で推移してきた。1960年 代前半では、全国平均は60\%程度であったが六ヶ 所村は $10 \%$ 程度であった（図 1)。

六ヶ所村の高校進学率が低迷していた理由は、 村内に高等学校がなく、かつ村の面積が非常に広 いために近隣高校へも通学が困難であり、進学に

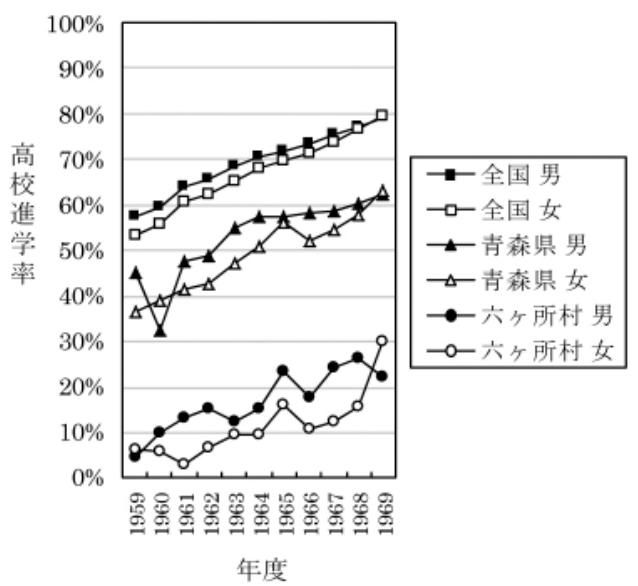

出典：学校基本調査、青森県教育委員会提供資料

図1 1960 年代の六ヶ所村の高校進学率
は多額の費用が掛かる下宿が不可欠だったことに よる。そのため、ほとんどの生徒は中学校を卒業 し就職していた。1960年代中頃までの中学生の 中心的な移行先は、県内の第一次産業である。例 えば1964年では、六ヶ所村の中学校を卒業した 402 名のうち、就職者の合計は343名。就職者の 内訳をみると県内の第一次産業が209名であり、 さらに第一次産業のうち漁業への就職者は 116 名 であった（青森県教育庁行政課 1964）。このよ うに県内第一次産業への従事者、漁業への従事者 の多さを考慮すれば、1960年代中頃までは中学 校の卒業後、半数以上の青年達が県内の第一次産 業へと従事し、村の産業の再生産構造は維持され てきたと考えられよう。実際、村の既存最大集落 である泊では、60年代中頃まで、中学生が釣り 子として労働の一端を担い中学校を卒業してその まま家業を継いでおり、高等学校進学問題は深刻 に考えられていなかったという指摘がある（福島 1978, P.164)。

そして、この第一次産業への移行の形は、60 年代後半に変容していく。中学校の生徒自身がイ カ釣り船の釣り子として乗ることが、児童労働と して問題とされるようになった。加えイカ釣り船 の機械化が進み、大人数の釣り子が不要となって きたのである。

このように、むつ小川原開発前においては青年 期（中学生）の移行は当初問題化しておらず第一 次産業の再生産が行われていた。しかし、移行先 がなくなったことで、移行が問題化するように なったといえよう。こうしたなか、1969年にむ つ小川原地域が開発対象となることが示され、 1971年には開発計画の第一次案が示されたが、 ちょうどこの1970年前後に、青年期の移行も大 きな変容を遂げていた。1972年には、村中学卒 業生 389 名のうち、進学者が 184 名、就職者が 186 名、うち県内就職者は 62 名で第一次産業への 就職者は 8 名、漁業は 0 名となったのである。竹 中によれば、進学せず就職をする青年達は県内企 業に加え、東京であれば工作機械やプレス、鍛造 などに、愛知であれば紡績工業などに就職した が、就職せずに家事手伝いに回るものも多かった 
という（竹中 1976）。

そして中学生の移行問題は、六ヶ所村だけの問 題ではなく青森県の全県的な課題であった。むつ 小川原開発を誘致した当時の竹内俊吉青森県知事 は、1971年の県議会で以下のように発言してい る（青森県 1971）。

例えば昭和三十二年以来の本県に出ました若 年労働者、一ころは中卒が圧倒的に多かったん でありますが、高校も入れまして去年までに 十七万二千万人出ております。いまでも一万人 出ておるのであります。その若い人たちは県外 の工業に八割以上就職しておる現状であります。 そういうことから考えますると、県内に何か第 二次工業を張りつけていくということは産業構 造改善という意味でも意味があると私は信じて います。

青森県では、県内に第二次産業を誘致すること で、第一次産業からの産業転換を図り若者雇用を 吸収することが目指されていた。そして、高等学 校の存在意義についても、開発と関連させながら 語られることとなる。

1969年にむつ小川原開発が示された後、むつ 小川原開発への激しい反対闘争が繰り広げられた が、開発計画の第一次案が示された後、開発に協 力した村民の生活の安定と向上を図るために「住 民対策大綱」が提示された。「住民対策大綱」では、 農家対策、漁家対策、商工業者対策、雇用対策、 社会福祉対策と並び、教育対策が示された。教育 対策について具体的にみてみると、教育水準の向 上や高校・大学への就学が目標とされているだけ でなく、さらに高等学校として工業高校が予定さ れていた（青森県 1972）。

$<$ 目標 $>$

. 開発区域住民子弟の教育水準の向上と、地域 の発展に寄与するすぐれた人材の養成

・ 高校と大学進学のための就学への経費節減

- 開発地区の小・中学校の児童・生徒の転校の 円滑化のための費用負担
$<$ 具体策 $>$

・ 移転に伴い生徒が急増する学校の校舎の新 設、増設

- 高校教育の機会拡充のための高校の新設（工 業高校) や学級数の増加、工業高専の新設

. 奨学金付与

中学生の移行の問題化は、県内に第二次産業を 誘致することで解決されようとしていたことが分 かる。更に、むつ小川原開発の受け入れと引き換 えに住民の高校設置要求も実現されようとしたの である。

\section{2 六ヶ所高等学校の開校からウラン濃縮施設 着工迄一教育機会の確保達成とむつ小川原 開発停帯による「荒れ」}

むつ小川原開発は1973年の第一次オイルショッ ク、1978年の第二次オイルショックのあおりを 受け、当初の予定通りには進まないという事態に なってくる。だがそのなかでも、住民の教育要求 にこたえることは進められた。15億円の学校設 置資金のほとんどがむつ小川原開発株式会社に よって出資され、1978年に青森県立六ヶ所高等 学校が開校したのである（石毛1998 p.221）。建 設された高校は、当初の住民対策で掲げられた工 業高校ではなく普通科高校であった。

住民対策には、工業高校などと明記されていた にもかかわらず、六ヶ所高校が普通高校として設 置された理由とは何だろうか。『六ヶ所村教育史 (改訂版)』には、「地域住民の雇用等の想定から、 工業高校の設置が基本構想のなかにあった。しか し地域住民の意向として『普通高校』に傾斜して いった。そこには素朴な疑問もなくはなかった （六ヶ所村教育委員会 1998）」と記されている。 また、『六ヶ所村史』では、六ヶ所高校は、むつ 小川原開発の賛否に住民が摇れるなかでの住民対 策としての側面が強かったが、教育の機会均等か ら考えると『開発の落とし子』として非難される いわれはない。経済開発ばかりでなく人材開発を 通して村の発展に寄与できることが期待されてい るが、工業高校から普通高校への傾斜を六ヶ所村 
民がこれをどう受け止めたのか、残念ながらよく 分からないとしている（六ヶ所村史編纂委員会 1997）。それではなぜ工業高校ではなく普通高校 として開校したのか。そして、高校は地域でどの ような役割を担うことになったのか。

普通高校として開校した経緯を辿ると、1975年 の六ヶ所村議会における教育委員長の次の発言に 行き当たる。高校を普通高校としたのは、むつ小 川原開発を進めた県ではなく、村の要望であった。

県立高校の誘致計画は県の計画の中に示され ている訳ですが、(昭和）52年にと言う事でござ います。計画を見ますと工業高校と言う事に なっている訳ですが工業高校と普通高校との併 校と言う考えである訳でございました、敷地の 方については青写真の方に高校の立てる場所は 県の方では取ってある訳ですが私の方つまり教 育委員会の考え方と言うのは高校に行く場合工 業高校よりもむしろ普通高校の方が良いのでは ないかと言う考え方を県の教育庁の方に申し述 べてある訳です。ただ県の方としては、当面の 対策として、すぐ工業高校卒業生を使うと言う ふうな意見もあって、工業高校と言うふうな事 になっております。将来を見通した場合普通高 校の方が良いのではないかと言う意見が申し述 べられた。ただ、具体的にどう言うふうな形に するかと言う事までは決まっておりません。そ う言う事です（六ヶ所村議会 1975)。

備考：括弧内は筆者記入

以上は当時の田中教育委員長の発言であるが、 発言のなかにある「高校に行く場合工業高校より もむしろ普通高校の方がよいのではないか」に着 目すると、村の教育委員会からは、工業高校とい う開発計画への人材供給の側面が強くなるもので はなく『六ヶ所村史』が述べていたような新たな 教育機会の提供の場としての高等学校を求めてい たと読み解くことができる。

こうした経緯を経て、1976年に、青森工業高校 内に仮称「青森県立六ヶ所高等学校」が設置され、
地元側の推進組織としての「六ケ所高校学校推進 協議会」も設立された。ところが、開校に向けて は、課題が山積みであった。村外への高校への進 学率が高まっていたこともあり当初の入学希望者 は26名しかなく、村内においても通学の問題が大 きな課題となったのである。そこで、検討の結果、 バス通学を行いバス代を村が半分負担することな どの環境整備に加え、村内中学校への説得の上、 ようやく志願者が 150 名程度にまで集まったので あった（青森県立六ケ所高等学校 1987）。

だが、六ヶ所高校が設立される以前から課題と なっていた中高生たちの「荒れ」という課題は静 まることはなった。高校生たちの生活行動の乱れ から、六ヶ所村では1976年に高校生への生徒指 導が村生徒指導協議会において指導重点事項とな り、「高校生友の会」の設立が謳われた。1978年 8月、「高校生の会」が設立された。会則第二条 では「会員相互の交流と親睦をはかり、健全な高 校生活を送ることを目的とする」と読まれている (六ヶ所村教育振興会 1978)。この会は村内中学 校を卒業した会費を納めた会員制とその協力者が 会員であり、通常総会や会報の発行などを行うも のであるが、実行委員会としては、体育委員会、 文化委員会、奉仕委員会が組織されている。役員 として名誉会長に村長や、顧問に教育長、校長会 代表が置かれている。これらのことを考慮すれ ば、「高校生の会」は、高校生の自立的な組織と いうよりも極めて行政的な組織であったといえ る。そして、この友の会へは参加者は、村内高校 生の約 5 分の 1 しかなく、高校生たちは、「なんと なくバカくさい」気持ちを持ち、「友の会」に名 を借りた「高校生の管理」であったことを見抜い ていたのではないかとも指摘されている（六ヶ所 村史編纂委員会 1997)。だがしかし、行政的な 組織を作ってまでも、高校生を管理しょうとした ほど、高校生の生活行動は悪化していたことが容 易に想像できよう。そして、その後も中高生の「荒 れ」は広がった。1985年には六ヶ所村の隣の野 辺地町において中学生のいじめ自殺事件が発生し た。六ヶ所村から開発の動乱によって土地を失い 野辺地町へと移住する者が増え、出稼ぎや遠洋漁 
業などから保護者が不在の子どもたちの間でいじ めが起きたことが指摘されている（久冨 1986）。 泊中学校では「校舎のガラスは二回はいれ替え た。ほとんどの電灯が吒きこわされた。万引き事 件も問題になった。五人の生徒が児童相談所に送 られた（鎌田1991 p.173）」という。

六ヶ所高校は開校したが、むつ小川原開発が頓 挫していたなかでの開校に、高校も“開発の落と し子”や“政治高校” “開発高校”というように 挪揄されることとなった。そして、六ヶ所高等学 校の『十年の歩み』には、「高校を職業訓練校や レストハウスと間違っているのではないかと思う ほど、高校生活に適応できない生徒が少し目に付 いた。そして、授業から帰ってくる先生達の疲れ た顔から指導の難しさや、悪戦苦闘の跡が偲ばれ ました。生徒もまた通学距離で悩まされたと思い ます（青森県立六ケ所高等学校 1987）」という教 員の投稿が寄せられている。住民達の暮らしに目 を向けても、土地は売ってしまったのに開発は来 ない。そうしている間に、核燃料サイクル計画が 持ち上がり、新しい開発への賛否がさらに地域や 家庭の人間関係を壊すというこの時期。学校設立 という教育要求は満たされたものの地域での住民 の生活そのものが極めて不透明であり、次の住民 となる青年たちをどのように育てていくのか、模 索すら難しかった時期であった（図 2 )。

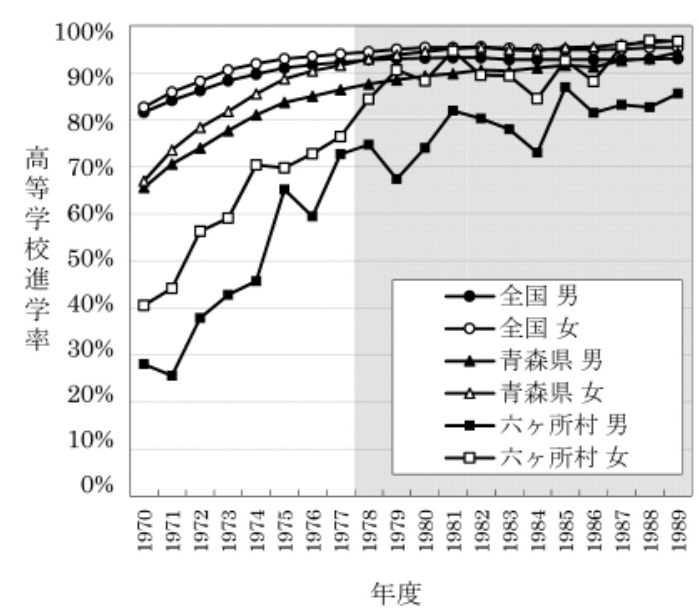

出典：学校基本調査、青森県教育委員会提供資料 図21970 80年代の六ヶ所村の高校進学率

\section{3 むつ小川原開発の本格的な核燃化以降 核燃} 化の中での移行先確保のジレンマ

1984年に電気事業連合会から青森県、六ヶ所村 へ核燃料サイクル施設立地の正式要請があり、 1985年に「原子燃料サイクル施設の立地への協力 に関する基本協定書」が締結された。その後、 1988年のウラン濃縮工場建設を皮切りに次々と核 燃料サイクル関連施設が建設され始めた。

秋元は村の産業構造について、とりわけ1980年 代末からの電源三法交付金を財源とする村発注工 事のため、六ヶ所村は農業・漁業を中心とした構 造から建設業へと産業転換し、村経済に過剩に建 設業が組み込まれるようになったことを指摘して いるが（秋元 2003 p.236）、六ヶ所高校の父母の職 業を見ても秋元の指摘と同様になっている。六ケ 所高校の保護者の職業も、農業、漁業水産養殖業 から建設業へと置き換わっていく（六ヶ所高校学 校要覧)。そしてここで着目すべきは、日本原燃 への労働は製造業へ分類されるが、製造業へ勤め ている父母はほとんどいないことである（図3）。

親世代は、農業から建設業に転換していくとい う形で核燃と経済的関係を有するようになってい くが、その一方で、なかなか核燃事業の本体を担 う会社へ就職することはできない。これは、六ヶ 所村で核然を推進したいと思う人の長年の悩みで あった。この悩みは、六ケ所高校への生徒への期 待と変わっていく。六ヶ所村議会の様子からは、 期待通りに六ヶ所高校から地元企業への就職が実 現しないために、地元企業に採用を依頼している 様子をたびたびうかがうことができる。

村はこれまで進出企業に対し村民雇用の拡大を 求めてまいりましたが、高度な技術と知識を要す る業務であるため、企業の求人と村民雇用にミス マッチが発生しており、なかなか期待するほどの 成果が上がっていないことも事実であります。(中 略) 加えて六ヶ所高校に高等専門学校のような高 いレベルのエネルギー関連教育を行う専門課程を 新設することにより、人材の掘り起こしにつなが るものと考えております（六ヶ所村議会 2005）。 


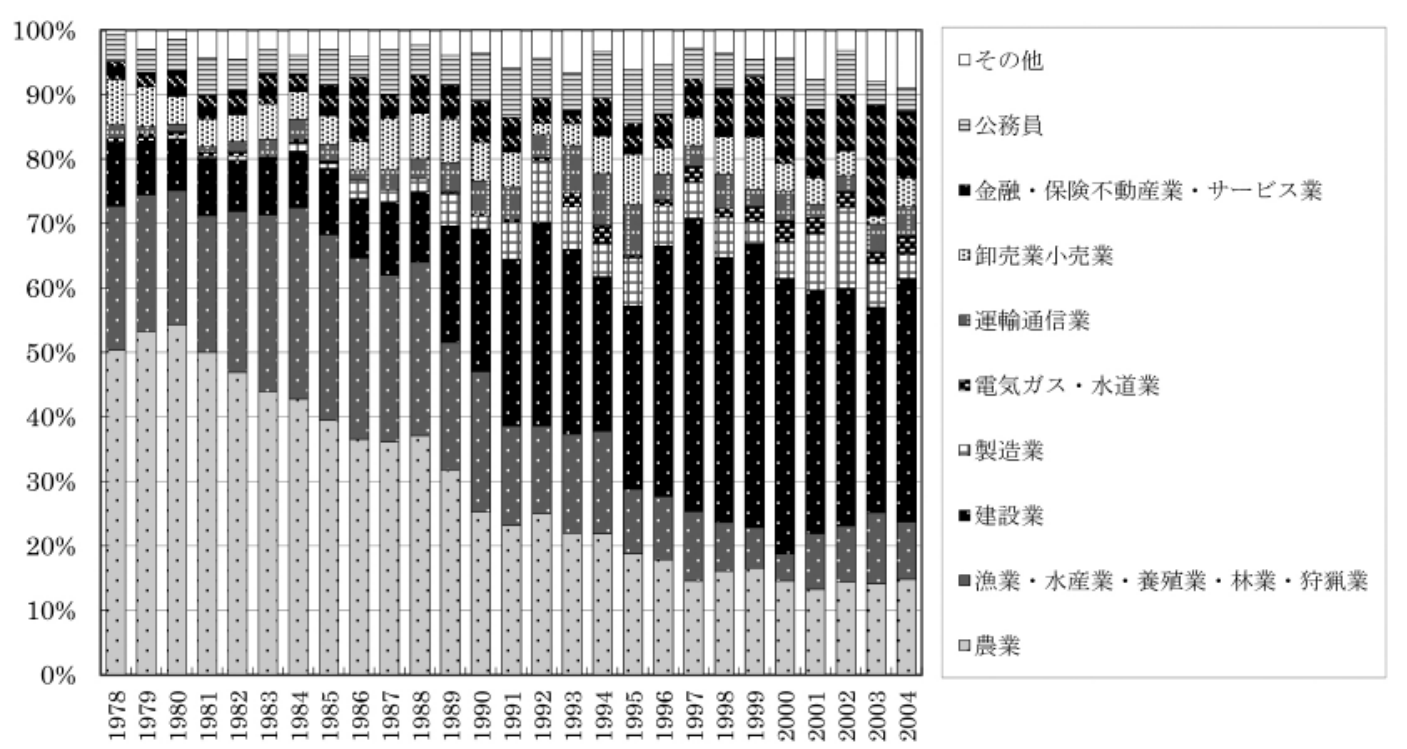

入学年度

出典 : 六ヶ所高等学校学校要覧

図 3 六ヶ所高校入学者の保護者職業

ただ単に頭が良い者、良い者採用で、いわゆ る体力とかやる気とか根性を見ないで、ただ学 力だけで判断して採用して、しかも地元ではな い方を採用して、地元ではない方もそれは仕方 がないでしょう、特殊なものに関しては。けれ どもできれば地元出身者を採用していただきた いと思います。

なぜかといいますと、私ども常々口酸っぱく なるぐらいAIS ですか、あそこにも地元出身 者を入れてください、原燃にもできたら地元採 用してください、そして六ヶ所高校出身者を とってくださいとロがすっぱくなるぐらい言っ て、私共が議会が要望し、村長も先頭に立って やっている中で、その自治体が村長が地元出身 者でない方を採用するということは、私はいか がなものかなと思いますが、このへんで魅力が ない、六高も特に魅力がないのではないかとい う気がしますが、一体そのへんどういう考えで すか（六ヶ所村議会 2005）。

普通高校として設立された六ケ所高校である が、移行の問題を背景に、議会では、六ヶ所高校
にエネルギー科の設置を要望する声が出された り、工業科を持つ近隣高校への入学を支援するよ うな要望も出されたりしている（六ヶ所村議会会 議録 2014 第 4 回定例会第 2 号)。この要因は、 六ケ所村に核燃料サイクル施設ができたものの、 専門性が必要となる職場のため、地元出身という だけで簡単に入社できる訳ではなく就職試験をパ スできる一定の学力が求められる。加えて、2004 年頃に少子化のあおりを受けた結果、六ヶ所高校 の入学者数の減少という課題が浮上し六ヶ所高校 の存続問題に発展した（図4)。そして、入学者 問題と移行問題の両方の解決方法として登場した のが、経済的手当と学力向上である。2005年度 から、六ヶ所村では六ヶ所高校存続のために新た な支援を開始した。村内から六ヶ所高校に通う生 徒は授業料の 3 分の 2 が免除、村内・近隣市町村 から六ヶ所高校へバス通学する生徒への交通費半 額免除などが施され、入学者数は回復した。

2010 年には、村が電気事業連合会及び日本原 燃に依頼し寄附された 2 億円を原資にした人材育 成基金を基に、大学、大学院の就学に伴う助成金 や普及啓発講座への助成金なども拡充された 


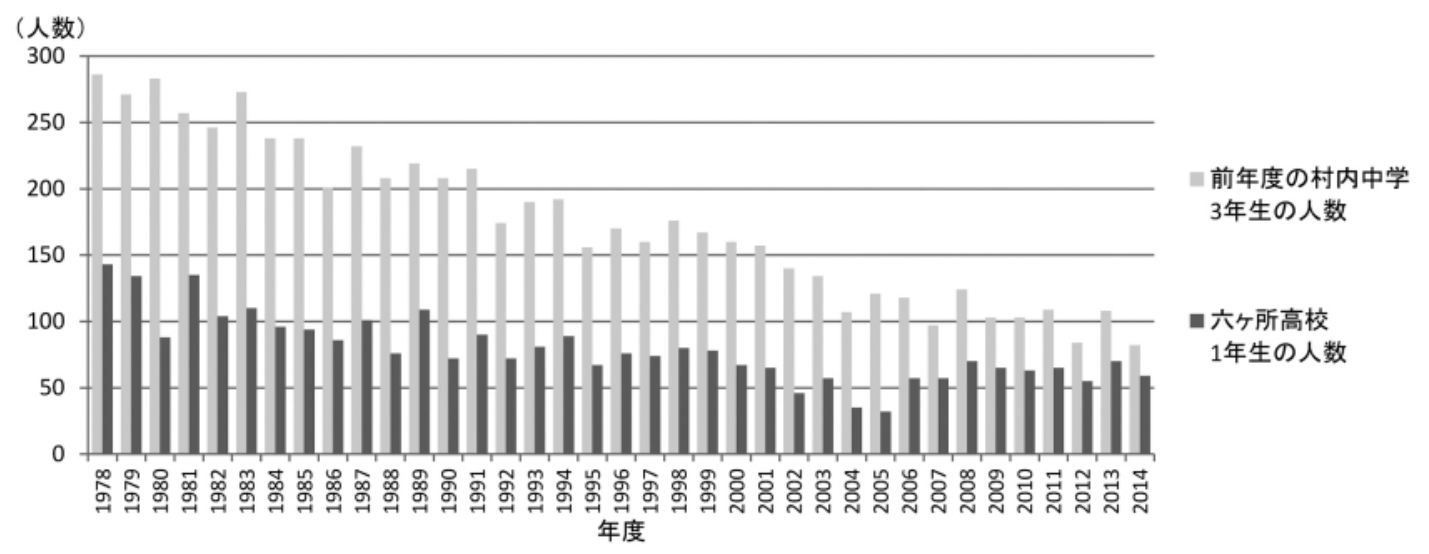

出典 : 文部科学省学校基本調査、六ヶ所高等学校学校要覧 図 4 六ヶ所高校の入学者数

(六ヶ所村議会会議録 2010)。経済的支援及び学 力向上の重点化は、核燃推進と一体化して進んで きたことが明らかであり、六ヶ所村がむつ小川原 開発に適応しょうとしてきた、あるいは、そうせ ざるを得なかった姿として捉えることができる。

ただし、ここには問題点も潜んでいる。秋元の 研究では、六ヶ所村の村民の所得は核然にかか わっているか否かで格差があることが示されてい る（秋元 2003）。この村に住み続け経済的に豊か に暮らしていきたいと思えば、青年たちは、核燃 にかかわるという進路選択をせざるを得ない状況 になる。一方、六ヶ所村に生まれ育っても、核燃 に批判的な感情を抱いている彼ら・彼女らは、就 職先が核燃と関係を有しているか否かを気にしな がら進路を決めたり、地元を離れたりといった選 択をせざるを得ない(2)。地域においてある特徵を 持った移行先が強く固定化したことにが、青年自 身への生き方のしがらみとなって新たに立ちはだ かってきたのである。

\section{$\mathrm{V}$ 結論 公害のリスクを抱える地域を巡る環境 教育研究の今後}

以上、青年期の移行問題を通じて、地域の公害 問題と教育とがどのような動的関係にあったのか を青森県六ケ所村を事例にみてきた。これらをま とめると、(1)むつ小川原開発前から石油型のむつ 小川原開発計画時（1960年代～1970年代）にお
いては、高校進学率は極めて低い状態であった が、第一次産業へと移行していたことで高校進学 の必要性が認識されていなかった。これが、県内 の第一次産業の形態が変化し県外への移行が増え たことから、移行問題が開発誘致必要性の理由の 一つとして語られ、高等学校建設という要求も実 現されようとしたことが分かった。次に、(2)六ヶ 所高等学校の開校からウラン濃縮施設着工迄 （1978年～1988年頃）は、石油型のむつ小川原開 発が停滞しながらも住民の念願の高校は建設に 至った。だが、開発停滞による地域社会や移行先 の不安定さからの影響を受けた生徒の「荒れ」が 多く報告されることとなった。そして最後に現代 に続く(3むつ小川原開発の本格的な核燃化以降 （1988年以降）においては、六ケ所高校への入学 者数の減少や村内での移行先の確保という課題 が、むつ小川原開発と関連付けられながら問題化 させられ、それらが経済的手当や学力向上という 方法をもって解消されようとしてきた。

本稿の事例を通じて見えてきたものは、六ヶ所 村にむつ小川原開発が降りかかり、地域が変化し てからというもの、住民自身がそもそもこの問題 にどう向き合いどのように生きるのかという葛藤 を抱え、さらにその中でどのように次の住民を育 てるのかという二重の葛藤を抱えざるを得なかっ たということである。つまり、「環境問題の解読 を、人の生き方と育ち方の、まさしく人間形成の 
課題（御代川・関2009 p.35）」として位置付ける 環境教育研究を志向するのであれば、迷いながら も原子力施設を受け入れることで地域の主体性を 取り戻そうとしてきた住民達は、その期待を教育 要求に反映させようと模索してきたということが できる。だが、公害問題の構造の下で戦略的にど のように生きていくのかという立場がある一方 で、公害の構造を相対化していこうとする立場も ある。確かに公害のリスクを抱えるこうした地域 では、公害教育実践を担う教師が不在となってし まっているが、そのことが公害に関する教育や学 習を現代において行うことが難しいということを 直接意味しているわけではない。なぜならば、こ うした地域には、いまでも地域の公害の構造の相 対化を試みる学習活動を個人的に続けている住民 達がいるからである。住民達の公害問題と教育を 巡る葛藤は住民達の生き様から見えるものであ る。そのため、今後は公害の構造の相対化を試み る住民達の生き様も読み解き、人間形成のなかで の課題を捉えていくことが必要である。これらを 環境教育研究として読み解いていくという作業は まだ十分に行われておらず、今後の課題であるだ ろう。加え、かつての公害教育実践を担った教師 が住民とともに地域調查や学習活動を行ったこと は、教育環境を守るという観点では住民に深く寄 り添っていたと思われる。ただし、り広い概念 としての教育環境である住民自身の生活課題（例 えば、六ヶ所村で言えば出稼ぎなどの課題）につ いて、教師はどのように寄り添ってきたのだろう かなどについては、今後の課題であるだろう。

\section{注}

(1) 2015年3月末現在はMOX燃料工場が建設中。 再処理工場以外は操業している。

(2) 筆者が 2008 年 9 月に教育関係者へ実施したイ ンタビュー調査による。

\section{引用文献}

秋元健治，2003，『むつ小川原開発の経済分析』， 創風社, 東京.

青森県, 1972,「住民対策大綱」.
青森県, 1971,「むつ小川原地域開発住民対策に関 する全員協議会会議録」.

青森県立六ヶ所高等学校「学校要覧」.

青森県立六ヶ所高校 1987, 『10年の歩み』.

藤岡貞彦, 1985, 「地域課題学習の教育的意義」, 国

民教育研究所環境と教育研究会編, 『地域開 発と教育の理論』, 大明堂, 東京, 220-241pp.

藤岡貞彦, 1977, 『教育の計画化』労働総合研究所, 東京.

藤岡貞彦, 1992 東京学芸大学野外教育実践施設編

『環境教育辞典』株式会社東京堂出版, 東京, p.81.

藤岡貞彦, 2000, 「教育的価值の社会的規定性」『 $<$ 教育と社会 $>$ 研究』第 10 号.

福島達夫, 1978, 「むつ小川原巨大開発と教師・住 民 六ヶ所村の村落構造」『国民教育』労働旬 報社, 東京, 140-165pp.

福島達夫 · 宮崎一郎 - 近津近津経史 -上川義昭, 1989,『原発」をどう教えるか』, 旬報社, 東京. 船橋晴俊, 1998, 編船橋晴俊 - 長谷川公一・飯島 伸子『巨大地域開発の構想と帰結 むつ小川原 開発と核燃料サイクル施設』東京大学出版会, 東京, 11-41pp.

飯島伸子, 1993, 『現代社会研究叢書 改訂版 環 境問題と被害者運動』, 学文社, 東京.

飯島伸子, 1998,「大規模開発下の地域社会の変 容」船橋晴俊 - 長谷川公一 - 飯島伸子編『巨大 地域開発の構想と帰結 むつ小川原開発と核燃 料サイクル施設』, 東京大学出版会, 東京, 191204pp.

石毛聖子, 1998, 「地域社会の変容と再構築」船橋 晴俊 ·長谷川公一・飯島伸子編『巨大地域開発 の構想と帰結 むつ小川原開発と核燃料サイク ル施設』, 東京大学出版会, 東京, 205-225.

鎌田慧, 1991,『六ヶ所村の記録 下』, 岩波書店, 東京 p.173.

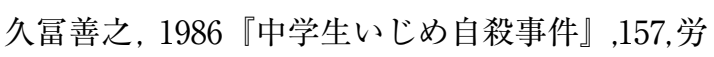
働旬報社, 東京.

中内敏夫・藤岡貞彦, 1979, 「発達を保障する教育 運動と教育計画」『岩波講座 子どもの発達と 教育 発達の保障と教育』, 岩波書店, 東京, 
279-324pp.

中内敏夫, 1985,「住民運動と学校の教育課程」,国

民教育研究所環境と教育研究会編, 『地域開

発と教育の理論』, 大明堂, 東京, 191-219pp.

宮原誠一, 1966,『青年期の教育』,岩波書店, 東京. 宮原誠一, 1976,『宮原誠一教育論集』,国土社, 東

京.

御代川貴久夫・関啓子, 2009,『環境教育を学ぶ人

のために』世界思想社, 京都.

六ヶ所村,2007,『六ヶ所村統計書平成 18 年版』.

六ヶ所村史編纂委員会, 1997,『六ヶ所村史下巻

II 』.

六ヶ所村教育委員会編, 1998,『六ヶ所村教育史

(改訂版)』.

六ヶ所村教育振興会, 1978,『教育の歩み』,27,154.

六ヶ所村議会 1975 年第 10 回定例会議事録（1975

年9月 29 日付け）。

六ヶ所村議会議事録, 1977,「第 3 回定例会,3月 17

日付」。

六ヶ所村議会会議録, 2005,「第 6 回定例会第 2 号

本文」

http://www.db-search.com/rokkasho-v/index. $\mathrm{php} / 8193827$ ?Query Type $=$ New（2014 年10月 30 日）。

六ヶ所村議会会議録, 2010,「第 1 回定例会第 3 号 本文」。

六ヶ所村議会会議録, 2014,「第 4 回定例会第 2 号

本文」

http://www.db-search.com/rokkasho-v/index. php/8193827?Query Type $=$ New（2014年10月 30 日）。

ザックス, ヴォルフガング, 2003, 『地球文明の未 来学 脱開発へのシナリオと私たちの実践』新 評論, 東京.

高橋正弘, 2013, 日本環境教育学会編，『環境教育 辞典』, 教育出版株式会社, 東京.

竹中司郎，1976,『むつ小川原開発による生活変化 と住民意識』未刊行.

ウィナー, ラングドン，2000, 『鯨と原子炉 技術 の限界を求めて』紀伊國屋書店, 東京.
六ヶ所村の高校進学率については下記の資料を用 いている。

青森県教育庁教育研究所, 1959 ～1961, 「中学校 卒業者の帰すう状況」等.

青森県教育庁行政課, $1962 \sim 1973$,「中学校卒業 者の進路状況」等。

青森県教育庁総務課, $1974 ＼mathrm{~ 1987, ~ 「 中 学 校 卒 業 ~}$ 者の進路状況」等.

青森県教育委員会, $1988 ２ 008$, 「中学校等卒業 者の進路状況」等.

青森県教育庁総務課, $1981 ＼mathrm{~ 1985, ~ 「 高 校 生 の 進 ~}$ 路状況」等。

青森県教育委員会, $1986 ２ 008$,「高等学校卒業 者の進路状況」等.

青森県立六ケ所高等学校,1987『十年のあゆみ』。 文部科学省『学校基本調査』。 